\title{
CD31 (JC70) expression in plasma cells: an immunohistochemical analysis of reactive and neoplastic plasma cells
}

\author{
Dhirendra Govender, Pranitha Harilal, Mahomed Dada, Runjan Chetty
}

\begin{abstract}
Aims-To investigate the immunohistochemical expression of CD31 (JC70) in normal and neoplastic plasma cells.

Methods-Plasma cells in bone marrow biopsies and extramedullary locations were examined. All extramedullary biopsies were formalin fixed and paraffin embedded. The bone marrow biopsies were fixed in formal acetic acid and embedded in paraffin wax. Twenty multiple myelomas (12 bone marrow and eight extramedullary deposits), 10 extramedullary plasmacytomas, and 30 biopsies with reactive plasma cells (10 bone marrow, 20 extramedullary biopsies) were stained with anti-CD31 (JC70) using the streptavidin-biotin detection system with diaminobenzidine as a chromogen. Antigen retrieval in bone marrow biopsies was achieved by pressure cooking. In all other biopsies, antigen retrieval was achieved by microwave pretreatment.
\end{abstract}

Results-All 20 extramedullary cases with reactive plasma cells showed intense membrane staining. Focal staining was detected in reactive plasma cells in bone marrow biopsies. Five of 10 plasmacytomas showed membrane staining. None of the cases of multiple myeloma, either medullary or extramedullary, showed any immunoreactivity for CD31.

Conclusions-CD31, a member of the immunoglobulin supergene family of cell adhesion molecules, is strongly expressed in extramedullary reactive plasma cells, focally in bone marrow reactive plasma cells, and occasionally in extramedullary plasmacytomas.

(f Clin Pathol 1997;50:490-493)

Keywords: CD31; cell adhesion molecules; plasma cells

University

Department of

Cellular Science,

University of Oxford,

United Kingdom

M Dada

Correspondence to:

Dr D Govender, Department of Anatomical Pathology,

University of Natal Medical

School, Private Bag 7 ,

Congella 4013, Durban

South Africa.

email: govendh

med.und.ac.za

Accepted for publication 12 March 1997 lial cells, and a monoclonal antibody to CD3 has been used as a marker of these cells. Antibody JC70 detects a formalin resistant epitope which is widely distributed on a variety of benign endothelial cells. In detailing the range of tissues stained by the antibody, it was noted that in fixed tissue sections JC70 staining is restricted to endothelial cells and occasional bone marrow plasma cells. ${ }^{2}$

Although several cell adhesion molecules have been identified in normal and neoplastic plasma cells, CD31 expression has not previously been reported in plasma cells in formalin fixed, paraffin embedded tissues outside of the bone marrow.

We noticed during diagnostic use that reactive (polyclonal) plasma cells showed intense membrane staining with the anti-CD31 antibody, JC70. This prompted an immunohistochemical study of CD31 expression in reactive and neoplastic plasma cells.

\section{Methods}

The study consisted of a cohort of 60 cases which comprised 20 cases of multiple myeloma, 10 cases of plasmacytoma, and 30 cases with reactive plasma cells. Conditions in which reactive plasma cells were encountered included Castleman's disease, Hodgkin's disease, and mixed chronic inflammation.

Formalin fixed, paraffin wax embedded tissue blocks of cases with reactive and neoplastic plasma cells were obtained from the archives of the department of anatomical pathology, University of Natal Medical School. These consisted of eight extramedullary deposits of multiple myeloma, 10 plasmacytomas, and 20 cases with reactive plasma cells. There were biopsies from various extramedullary sites, including soft tissue abscesses, granulation tissue, reactive lymph nodes, perivascular chronic inflammatory infiltrates in skin, and so on. Formal acetic acid fixed, paraffin wax embedded tissue blocks of bone marrow trephine biopsies were retrieved from the files of the university department of cellular science, University of Oxford. These comprised 12 cases of multiple myeloma and 10 cases with reactive plasma cells, including five cases that had normal haematological indices. None of the 12 multiple myeloma cases had evidence of concurrent extramedullary deposits.

Tissue sections of $2 \mu \mathrm{m}$ thickness were mounted onto poly-L-lysine coated glass slides (Sigma Diagnostics, St Louis, Missouri, USA). The sections were then heat fixed for 10 minutes at $60^{\circ} \mathrm{C}$ and deparaffinised. Antigen retrieval was achieved by microwave pretreatment (H2500 microwave processor, Energy Beam Sciences, Agawam, Massachusetts, USA) in a $0.01 \mathrm{M}$ trisodium citrate solution $(\mathrm{pH} 6.0)$ for 10 minutes at $85^{\circ} \mathrm{C}$. The bone 
Table 1 Plasma cell immunoreactivity with CD31

\begin{tabular}{llll}
\hline & Extramedullary & Medullary & Total \\
\hline Reactive & $20 / 20$ & $10 / 10$ & 30 \\
Plasmacytoma & $5 / 10$ & - & 10 \\
Multiple myeloma & $0 / 8$ & $0 / 12$ & 20 \\
\hline
\end{tabular}

marrow sections were mounted on silane coated glass slides. They were processed in a similar way to that described above, but antigen retrieval in these cases was facilitated by pressure cooking.

Endogenous peroxidase activity was blocked using an aqueous solution of $3 \%$ hydrogen peroxide. Sections were stained with monoclonal anti-CD31 antibody (JC70: Dako A/S, Copenhagen, Denmark; dilution 1/30) using the peroxidase labelled streptavidin-biotin kit (Dako). The reaction was visualised using diaminobenzidine (Liquid DAB, Dako) as a chromogen. Endothelial cells and megakaryocytes in the tissue sections were used as positive controls. Negative controls, in which the primary antibody was withheld, were also run simultaneously. In addition, all bone marrow sections were stained with monoclonal antibody VS38c (Dako, High Wycombe, UK; prediluted) to assess the number of plasma cells present. In all cases, light chain immunostaining was reassessed using kappa and lambda light chains (Signet Laboratories, Dedham, Massachusetts, USA; prediluted, polyconal).

\section{Results}

The main results are shown in table 1 .

All 20 extramedullary biopsies with reactive plasma cells showed intense cytoplasmic membrane staining with CD31 (fig 1). The number of reactive plasma cells that stained varied from $75 \%$ to $100 \%$ of at least 100 cells counted per slide. In contrast, reactive plasma cells in the 10 bone marrow sections showed focal membrane staining only.

Five of the 10 plasmacytomas also showed membrane immunoreactivity for CD31. The remainder were negative. None of the cases of multiple myeloma, including both bone mar-

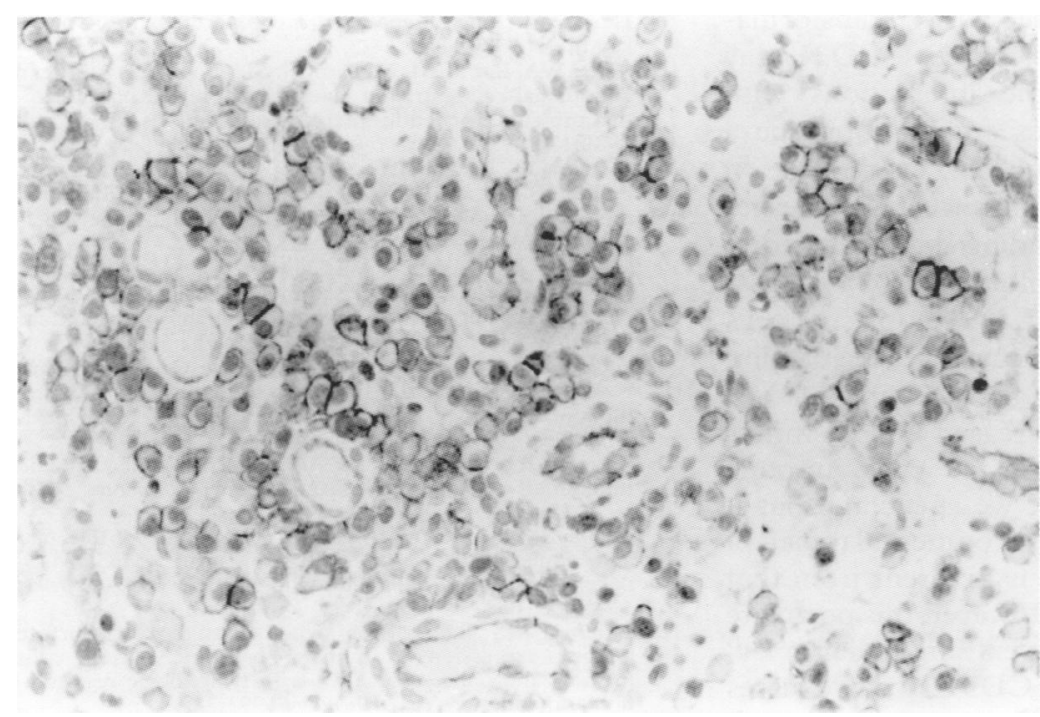

Figure 1 Chronic inflammatory infiltrate with reactive plasma cells showing intense membrane labelling with anti-CD31 (FC70) using the streptavidin-biotin technique. Endothelial cells of resident vessels are also positive. row sections and extramedullary deposits, showed any reactivity (fig 2 ). Internal controls in these cases were positive.

When applying $\chi^{2}$ and Fisher's exact test to compare CD31 expression in reactive (polyclonal) and neoplastic (monoclonal) plasma cells, statistically significant $p$ values of $<0.01$ and $<0.05$ respectively, were obtained.

Monoclonality was confirmed in all plasmacytomas and multiple myelomas. In reactive plasma cells, polytypic light chain expression was noted. All reactive plasma cells and myeloma cells in the bone marrow stained with VS38c.

\section{Discussion}

The molecules belonging to the immunoglobulin supergene family show diversity in cellular distribution and function. All members of the IgSF share a common structure, the immunoglobulin homology unit. ${ }^{1}$ Molecules belonging to this family include the major histocompatibility molecules, the $T$ cell receptor, the platelet derived growth factor receptor, colony stimulating factor-1 receptor, VCAM, ICAM-1 (CD54), NCAM (CD56), carcinoembryonic antigen (CEA), and PECAM-1 (CD31). ${ }^{3}$ Their diverse functions consisting of a number of homophilic and heterophilic cell interactions ${ }^{3}$ include those occurring during development (NCAM), ${ }^{45}$ inflammation and wound healing (ICAM-1, VCAM-1), ${ }^{67}$ and possibly in neoplasia (CEA) ${ }^{8}$

CD31 is a transmembrane glycoprotein found on the surface of platelets and its precursors, monocytes, granulocytes (neutrophils, basophils, and eosinophils), some $\mathrm{T}$ cells and B cells, mantle zone lymphocytes, synovial lining cells, and at endothelial intercellular junctions. ${ }^{9-13}$ Although the precise functions of CD31 are not clear, evidence suggests that it is an important vascular cell adhesion molecule involved in endothelial cell-cell adhesion. CD31 mediates cell adhesion by participating in a number of complex ligand interactions. It can interact both with itself (homophilic interaction) and with other nonCD31 molecules (heterophilic interactions). ${ }^{1415}$

The JC70 antibody detects an antigen identical to that detected by CD31 antibodies. JC70 was found to be a more reliable marker of malignant endothelial cells than the traditionally used endothelial markers, factor VIII related antigen and Ulex europaeus. Furthermore, JC70 showed more intense staining in malignant endothelial cells compared with normal endothelial cells. ${ }^{2}$

Several cell surface molecules, including adhesion molecules, have been demonstrated on normal and neoplastic plasma cells. ${ }^{16-19}$ Hamilton $e t a l^{16}$ found that myeloma cells expressed ICAM-1 (CD54). Later, Barker et $a l^{20}$ found that CD54 was expressed by both normal and neoplastic plasma cells. Van Camp et al ${ }^{17}$ showed that CD56 (NCAM) - an antigen associated with natural killer cells - was present on multiple myeloma cells. Other studies ${ }^{17} 1921$ have shown that CD56 was expressed on normal plasma cells, overexpressed on multiple myeloma cells, 


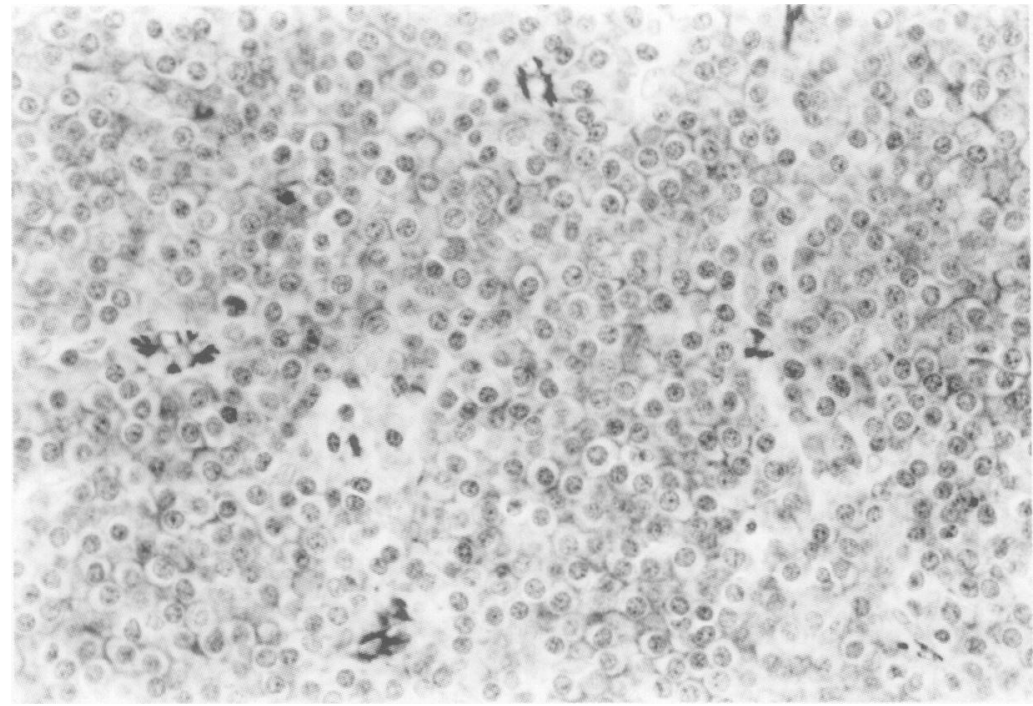

Figure 2 An extramedullary deposit of multiple myeloma showing no reactivity of the plasma cells with anti-CD31 (fC70). Once again, the inbuilt positive control of immunopositive endothelial cells is apparent.

and downregulated on bone marrow plasma cells in cases of multiple myeloma with extramedullary spread. In contrast to these findings, Barker et $a l^{20}$ found that CD56 expression was uncommon in normal plasma cells: staining was observed in only one of 10 cases.

It has been suggested that adhesion molecules have a functional role in the interactions of myeloma cells with the bone marrow environment. For example, CD56 has been implicated in cellular contact between osteoblasts and myeloma cells. Loss of CD56 expression has often been postulated to play a role in the dissemination of myeloma cells out of the bone marrow. ${ }^{17} 21$

CD31 expression on plasma cells in surgical biopsy material has not been reported previously. We have shown that CD31 is expressed strongly in all extramedullary reactive plasma cells, focally in bone marrow reactive plasma cells and in some extramedullary plasmacytomas, but not at all in multiple myeloma cells in either medullary or extramedullary locations. The loss of this molecule most probably occurs during the process of neoplastic transformation. In the inflammatory process, CD 31 may participate in heterotypic interactions with other adhesion molecules and this may be a reason for the high CD31 expression in reactive plasma cells. It is uncertain whether other mechanisms - including chemical mediators of inflammation-influence CD31 expression. The precise role of CD31 in plasma cells is presently unclear but further investigation may reveal its function in these settings.

The reason for the decreased CD $31 \mathrm{immu}-$ nostaining in reactive plasma cells in bone marrow is unknown, but we speculate that it may be due to the local environmental milieu of the bone marrow, which is different from that of extramedullary sites. However, this postulate does not hold true for the extramedullary plasmacytomas, where five CD31 positive cases were encountered. The decreased staining of reactive plasma cells in the bone marrow cannot be ascribed to the acid fixation of bone marrow specimens because the internal controls were positive for CD31.

This is the first study to look at JC70 staining in plasma cells. We have added to the list of cells known to be immunoreactive for the JC70 antibody and shown that reactive extramedullary plasma cells in routinely fixed tissues strongly express CD31. Finally, we are not advocating the use of anti-CD31 to differentiate between reactive and neoplastic plasma cells but emphasise the intense immunopositivity shown by extramedullary reactive plasma cells, and the immunohistochemical presence of another cell adhesion molecule in plasma cells. Further investigation is necessary to determine the reasons for the staining differences of plasma cells for CD31 in reactive preneoplastic conditions, such as monoclonal gammopathy of uncertain significance and neoplastic states.

We thank Gill Flack from the Cellular Pathology Department, John Radcliffe Hospital, Oxford, for assisting with the immunohistochemical staining of bone marrow sections.

1 Pignatelli M, Vessey CJ. Adhesion molecules: novel molecular tools in tumor pathology. Hum Pathol 1994;25:849-56.

2 Parums DV, Cordell JL, Micklem K, Heryet AR, Gatter KC, Mason MY. JC70: a new monoclonal antibody that detects vascular endothelium associated antigen on routinely procvascular endothelium associated antigen on routin

3 Williams AF, Barclay AN. The immunoglobulin superfamily: domains for cell surface recognition. Annu superfamily: domains for cell

4 Cunningham BA, Hemperley JJ, Murray BA, Prediger EA Brackenbury R, Edelman GM. Neural cell adhesion molecule: structure, immunoglobulin-like domains, cell surface modulation, and alternative RNA splicing. Science 1987;236:799-806.

5 Edelman GM. Morphoregulatory molecules. Biochemistry 1988;27:3533-43.

6 Wawryk SO, Novotny JR, Wicks IP, Wilkinson D, Maher D, Salvaris E, et al. The role of the LFA-1/ICAM-1 interaction in human leukocyte homing and adhesion. Immunol Rev in human leukocy

7 Elices MJ, Osborn L, Takada Y, Crouse C, Luhowskyl S, Hemler M, et al. VCAM-1 on activated endothelium interacts with the leukocyte integrin VLA-4 at a site distinct from the VLA/4/fibronectin binding site. Cell 1990;60:57784.

8 Benchimol S, Fuks A, Jothy S, Beauchemin N, Shirota K, Stanners CP. Carcinoembryonic antigen, a human tumor marker, functions as an intercellular adhesion molecule. Cell 1989;57:327-34

9 Von dem Borne AEG, Modderman PW, Admiraal LG, Nieuwenhuis HK. Joint report of the platelet section. In Knapp W, Dörken B, Gilks WR, et al, eds. Leucocyte typing IV: white cell differentiation antigens. Oxford: Oxford UniverIV: white cell differenticio

10 Muller WA, Ratti CM, McDonnell SL, Cohn ZA. A human endothelial cell-restricted externally disposed plasmalemmal protein enriched in intercellular junctions. $\mathcal{f}$ Exp Med 1989;170:399-414.

11 Newman PJ, Berndt MC, Gorski J, White GC, Lyman S Paddock C, et al. PECAM-1 (CD31) Cloning and relation to adhesion molecules of the immunoglobulin gene superfamily. Science 1990;247:1219-22.

12 Skubitz KM, Goueli SA. CD31 (PECAM-1), Cdw32 (Fc $\gamma$ RII), and anti-HLA class I monoclonal antibodies recognize phosphotyrosine-containing proteins on the surface of human neutrophils. F Immunol 1994;152:5902-11.

13 Stockinger H, Gadd SJ, Eher R, Majdic O, Schreiber W, Kasinrerk W, et al. Molecular characterization and Kasinrerk W, et al. Molecular characterization and functional analysis of the leuk

14 DeLisser HM, Newman PJ, Albelda SM. Molecular and functional aspects of PECAM-1/CD31. Immunol Today 1994;15:490-5.

15 Albelda SM, Muller WA, Buck CA, Newman PJ. Molecular and cellular properties of PECAM-1 (endoCAM/CD 31): a novel vascular cell-cell adhesion molecule. $f$ Cell Biol 1991 114:1059-68

16 Hamilton MS, Ball J, Bromidge E, Franklin IM. Surface antigen expression of human neoplastic plasma cells includes molecules associated with lymphocyte recirculation and adhesion. Br F Haematol 1991;78:60-5.

17 Van Camp B, Durie BGM, Spier C, De Waele M, Van Rie $\mathrm{I}$, Vela E, et al. Plasma cells in multiple myeloma express a natural killer cell-associated antigen: CD56 NKH-1:Leu19). Blood 1990;76:377-86. 
18 Van Riet I, De Waele M, Remels L, Lacor P, Schots R, Van Camp B. Expression of cytoadhesion molecules (CD56, CD54, CD18 and CD29) by myeloma plasma cells. $B r \mathcal{F}$ Haematol 1991;79:421-7.

19 Pellat-Deceunynck C, Barillé S, Puthier D, Rapp M-J, Harousseau J-L, Bataille R, et al. Adhesion molecules on Harousseau J-L, Bataille $R$, et al. Adhesion molecules on
human myeloma cells: significant changes in expression human myeloma cells: significant changes in expression tion. Cancer Res 1995;55:3647-53.
20 Barker HF, Hamilton MS, Ball J, Drew M, Franklin IM. Expression of adhesion molecules LFA-3 and N-CAM on normal and malignant human plasma cells. $\mathrm{Br} \mathcal{f}$ Haematol 1992;81:331-5.

21 Pellat-Deceunynck C, Bataille R, Robillard N, Harousseau J-L, Rapp M-J, Juge-Morineau N, et al. Expression of CD28 and CD40 in human myeloma cells: a comparative study with normal plasma cells. Blood 1994;84:2597-603. 